Eds Norman C. Rosen, Paul Weimer, Sylvia Maria

Coutes dos Anjos, Sverre Henrickson, Edmundo

Marques, Mike Mayall, Richard Fillon, Tony

D'Agostino, Art Saller, Kurt Campion, Tim Huang,

Rick Sarg, and Fred Schroeder.

http://dx.doi.org/10.5724/gcs.12.32.0701

http://archimer.ifremer.fr/doc/00316/42695/

(c) 2012 by GCSSEPM Foundation

\title{
The "Sink" of the Danube River Basin: The Distal Danube Deep-Sea Fan
}

\author{
Lericolais Gilles ${ }^{1}$, Bourget Julien ${ }^{2}$, Jorry Stephan ${ }^{3}$, Popescu Irina ${ }^{4}$, Abreu Victor ${ }^{5}$, Jouannic Gwenael ${ }^{6}$, \\ Bayon Germain $^{7}$
}

\footnotetext{
${ }^{1}$ IFREMER, Direction of the European and International Affairs, 155 rue Jean-Jacques Rousseau, Issy les Moulineaux, F-92138 France

${ }^{2}$ Centre for Petroleum Geoscience, School of Earth and Environment, The University of Western Australia, 35 Stirling Highway, Crawley, WA 6009, Australia

${ }_{3}$ IFREMER, Centre de Brest, Géosciences Marines, BP 70, Plouzané, F-29280, France

${ }^{4}$ GeoEcoMar, 23-25 Dimitrie Onciul Street, RO-024053 Bucharest, Romania

${ }^{5}$ ExxonMobil Upstream Research Company, 5959 Las Colinas Blvd., Irving, Texas 75039, United State

${ }^{6}$ CNRS, UMR 7193, ISTeP, Case 129, 4, place Jussieu, cedex 05, Paris, F-75252, France

7 IFREMER, Centre de Brest, Géosciences Marines, BP 70, Plouzané, F-29280, France
}

\begin{abstract}
:
The Danube River Basin and the Black Sea represent a unique natural laboratory for studying source to sink and global change. We will address information on the "active sink" of the system, which represents the area of active deposition: sea level variation, sediment balance, and neotectonics. Also, we will discuss the evolution and quantification of climate, tectonics, and eustasy on the sedimentation in the western Black Sea basin, along both southern and northern margins, obtained from understanding the Danube deep-sea fan processes and sedimentation.
\end{abstract}

In the last decade, many of the geosciences studies carried out in the Black Sea have focused on the Holocene marine transgression. This topic has been fully discussed and is still a matter of debate. Since the DSDP drillings, the lithology and mineralogy of deep sediments from the Black Sea have been well studied. However, only few recent studies have focused on the deep-sea morphology and turbidite sedimentation in the western Black Sea basin, in which the main depositional feature is the Danube submarine fan.

Oceanographic surveys in the Black Sea in 1998, 2002, and 2004 carried out in the framework of French-Romanian joint project and the European ASSEM-BLAGE (EVK3-CT-2002-00090) project have collected a large amount of data (Multibeam echo sounder data, CHIRP seismic, as well as Kullenberg and Calypso cores). This paper presents insights from recent coring and seismic data recovered at the boundary of influence of both the distal part of the Danube turbiditic system and the Turkish margin. This data set provides a good record of changes in the sedimentary supply and climatic changes in the surrounding Black Sea since the last 25 ka. Based on this study, we 
demonstrate that the deep basin deposits bear the record of the late Quaternary paleoenvironmental changes.

Finally, the western Black Sea basin constitutes an asymmetric subsident basin bordered by a northern passive margin containing confined mid-size, mud-rich turbiditic systems, and a tectonically active southern turbiditic ramp margin 


\section{Introduction}

The nature and rate of differing geomorphic-climatic processes that deliver sediments from the source to the sink (mountains to deep sea fan) vary markedly in tectonically stable and tectonically active settings. The parameters controlling the connectivity amongst late orogenic semi-isolated basins, and with open marine environments, respectively, are complex. This results in significant variability in sediment transfer relationships. They are influenced, for example, by interplay between uplift and subsidence creating accommodation space and building sediment source areas (Cloetingh et al., 2007). The two most important factors that influence sedimentation in a sink are changes in sediment supply and water level. One of the most important European sources to sink system is the Alps/Carpathians/Pannonian Basin system drained by the Danube River ending onshore by its famous Delta (Matenco et al., 2011). This system continues offshore using the unique important pathway still marked on the underwater morphology: the Viteaz canyon (Popescu et al., 2004). The sink part of this system is constituted by the Danube deep sea fan studied by Popescu et al. (2001) and recently by Lericolais et al. (2012). The Alps/Carpathians/Pannonian and Danube/Black Sea system represents a unique natural laboratory for studying the interplay between lithosphere and surface processes and the source to-sink relationship.

Many authors (Flood et al., 1999; Konyukhov, 1997; Wong et al., 1994; Wong et al., 1997) have recognized that sedimentation in the Black Sea was influenced by eustatic sea level changes driven by global glaciations and deglaciations. However, most of these studies have not confirmed that the water level of the Black Sea was controlled by eustatic changes only to a certain extent. Since then, oceanographic surveys have focused on the deep-water architecture and sedimentation in the western Black Sea basin, where the main depositional feature is the Danube deep-sea fan (Lericolais et al., 2012; Popescu et al., 2006; Popescu et al., 2004; Popescu et al., 2001; Winguth et al., 2000): (1) to study the nature of the deposits and the associated sedimentary processes, (2) to understand the stratigraphical evolution of the sedimentary deposits, (3) to provide a scenario on the evolution and 
quantification of climate, tectonic and eustasy forcing on the sedimentation in the western Black Sea basin, along both southern and northern margins.

The examination at an appropriate scale of sediment path-ways dispersion across the continental shelf towards the slope and the deep sea zone and then of their deposition, compaction and/or possible sliding represents a case study for deciphering the in and out of sediment loads and water fluxes produced during the melting of the ice after the deglaciation. The Danube system is the pathway of the melting produce from the Alps and the Black Sea the end member.

From three major oceanographic surveys carried out in the Black Sea in 1998 (BlaSON1), 2002 (BlaSON2) and 2004 (ASSEMBLAGE) in the framework of French-Romanian joint project and the European ASSEMBLAGE project (EVK3-CT-2002-00090), an important set of data (Multibeam echosounder data, Chirp seismic, Kullenberg and Calypso cores) have been collected. A recent good record of the changes in the sedimentary supply and climato-eustasy in the Black Sea region during the last $25 \mathrm{ka}$ was recently published (Lericolais et al., 2012). This study demonstrates that the deep basin deposits bear the record of the Late Quaternary paleoenvironmental changes. These results combined with previous studies tried to demonstrate that the basin floor deposits from this portion of the western Turkish margin could result of mud-rich gravity currents originated from multiple masswasting events along the steep Turkish slope. Such events could be triggered by the earthquake activity of the North Anatolian Fault. The very fine grained trend in the deep basin turbidites is due to a combination of the availability of fine-grained material on the shelf and rapid deposition of the coarser sediments at the abrupt slope break.

A complementary work realised on the cores recovered during the above mentioned surveys was realised using combination of $\mathrm{Lu}-\mathrm{Hf}$ and $\mathrm{Sm}-\mathrm{Nd}$ isotope in order to decipher the origin of surficial sediments in the western Black Sea. Such systems offers a potentially unique perspective for investigating continental erosion (Bayon et al., 2009b). Hf and Nd elemental and isotope data are used to confirm that the main provider of the sediment of the deep sea fan is the Danube river and to see to what extend the Anatolian shelf and rivers could have been responsible of the last sedimentation process recognized at the distal part of the deep sea fan. 


\section{Geological setting}

The Black Sea is a land-locked basin of ca $432.000 \mathrm{~km}^{2}$, connected to the Mediterranean Sea by the Bosphorus Strait. The western Black Sea basin is generally considered to be the result of backarc extension associated with the northward subduction of the Tethyan plate. (Robinson et al., 1995). The north-western Black Sea, infilled by thick sedimentary successions of up to $19 \mathrm{~km}$ since the Cretaceous, is the main depocentre for sediment supply from Central Europe via the Danube River and from Eastern Europe through the Ukrainian rivers Dniepr, Dniestr and Southern Bug (Robinson et al., 1995) These sediment supplies contributed to the shaping of the north-western Black Sea margin from the coastal area, marked by deltaic deposits, down to the deep basin, where large deep-sea fan complexes including the Danube deep-sea fan formed (Lericolais et al., 2012; Popescu et al., 2001; Wong et al., 1994) (Figure 1).

The northwestern continental shelf reaches up to $170 \mathrm{~km}$ wide off the Dniepr River and the shelfbreak is located at water depths of -120 to -140 m southward of the Danube Canyon, and up to $-170 \mathrm{~m}$ northward of the canyon possibly due to recent faulting (Figure 2). A relatively steep slope (2.5\%) lies between the shelfbreak and the flat abyssal plain (2200 m water depth) (Popescu et al., 2004). The continental slope is dissected by numerous canyons which commonly stop at the shelfbreak with the exception of the Danube Canyon which deeply incised the shelf for $26 \mathrm{~km}$ landward (up to $-110 \mathrm{~m}$ water depth). The Danube Canyon acted as a major gateway for the sediment transfer towards the deep Black Sea (Popescu et al., 2004). In addition to terrigeneous supply, river inputs constantly introduced high amounts of organic-rich material into the Black Sea. The specific history of the Black Sea, including times of periodical sea bottom anoxia, created particularly favourable conditions for the decomposition of organic matter and for gas generation.

Submarine fan activity was controlled by changing sea level. In the marginal basin of Black Sea, the sea level development was complicated by the link to the Mediterranean through the Strait of Bosphorus and the Sea of Marmara. When the Mediterranean water level fell below the Bophorus during glacial periods, the Black Sea was isolated from the world ocean (Ross, 1978) and its level oscillated synchronously with the wet-dry cycles in Eurasia. At the same time, the Black Sea 
catchment areas were considerably enlarged, redirecting part of the meltwater discharge towards the Caspian Sea, the Black Sea and the Mediterranean (Arkhipov et al., 1995). Temporary absence of marine water influx associated with large freshwater inputs from the Danube and other important rivers changed the Black Sea in a freshwater lake during times of fan activity, thus creating special conditions for turbidite deposition (Flood et al., 1999). A re-establishment of the connection to the Mediterranean during highstands resulted not only in a rise in the water level of the Black Sea and interruption of fan activity, but also in an increase in salinity, the Black Sea becoming a highlystratified marine anoxic basin. Presently, the Black Sea is the world's largest permanently anoxic basin, with a surface layer of aerated brackish waters and deeper more saline and anoxic waters. Sedimentary discharge is directed mostly southward along the western coast as a consequence of the prevalent winds and currents (Panin, 1997).

\section{Danube deep sea fan settings}

Beyond the continental shelf is a complex system of canyons, channels, accumulative sedimentary bodies leading to deep-sea fans (Popescu et al., 2004; Popescu et al., 2001) (Figure 2). The Danube deep-sea fan which can be considered as a potential hydrocarbon field, developed in the north-western part of the Black Sea from sediments fed by the Danube but also by the northern rivers: the Dniepr, the Dniestr and the Bug (Popescu et al., 2004; Winguth et al., 2000). It extends for about $150 \mathrm{~km}$ downslope of the shelf break, and the distal end of the fan reaches the abyssal plain at $2200 \mathrm{~m}$ water depth. Depositional processes are located essentially on the middle and lower slope.

The Danube deep-sea fan (or turbidite system) is developed in the north-western part of the Black Sea, fed by sediments from the Danube (Popescu et al., 2004; Winguth et al., 2000), whereas the northern fan (Dniepr deep-sea fan) was fed by eastern rivers: the Dniepr, the Dniestr, and the Bug.

The development of the northern turbidite complex supplied by the Dniepr and the other Ukrainian rivers appears independent but coeval. Winguth (1998) and Winguth et al. (2000) estimated ages of ca. $900 \mathrm{ka}$ for the Danube fan and ca. $800 \mathrm{ka}$ for the Dniepr fan. Both fans are composed primarily of channel-levee systems, intercalated with mass transport deposits. Wong et al. (1994; 
1997) separated eight seismic sequences in each of these fans; only the six upper sequences, however, contain large meandering channel-levee systems.

The youngest channel-levee system on the Danube deep-sea fan developed most probably during the Neoeuxinian lowstand in a freshwater basin (Soulet et al., 2010) with a water level at least $100 \mathrm{~m}$ lower than that of today. Sediments supplied by the Danube were transported over the narrow shelf to the deep basin through the Viteaz (or Danube) canyon, which was directly connected to the leveed channel of this system. Distinct HARP units associated with six bifurcations in this channellevee system have been identified on the middle fan (Lericolais et al., 2012; Popescu et al., 2004).

A definite relationship exist between water level and Danube fan sedimentation: when water level is close to the shelfbreak during lowstands, fluvial sediments are transported to the deep-sea fan, while fan construction is essentially interrupted during water level highstands. However, several bifurcations developed during a single lowstand (Neoeuxinian - stage 2), so that channel avulsion and sand delivery are not directly related to water level fluctuations; rather, the primary control is autocyclic.

The Coriolis effect, on the other hand, is a factor that strongly influenced channel bifurcation. The right levee looking down-channel is higher (first order influence of the Coriolis force). The six units identified can be related to avulsion phases initiated by breaching of the lower and narrower left levee, which resulted in a migration of the active channel towards the left. Therefore, the northward migration pattern of the last channel-levee system is likely to be the result of second order of Coriolis effect.

Fan growth in a semi-freshwater basin produced essentially the same basic depositional features as in a marine basin. The seismic and sedimentary facies are similar to those described in most large mud-rich fans, so that the same depositional processes must have been active. Nevertheless, the semi-freshwater environment harbors a greater density contrast to the inflowing river water than a marine environment. This possibly induced the prevalence of hyperpycnal flows, and with it a higher frequency and larger size of turbidity currents. Movement of these flows was under the influence of the Coriolis force. However, the question whether the Coriolis effect on fan deposition was stronger in the semi-freshwater Black Sea compared with a marine environment remain unanswered. 
Numerous studies including Ryan et al. (1997), Major et al. (2002a; 2006; 2002b) or Lericolais et al. $(2010 ; 2011 ; 2007 a ; 2007 b)$ have shown that the relative sea level at glacial times was between 90 and $150 \mathrm{~m}$ below the present day sea level. As consequence, the present day shelf of the north-western margin was exposed and the Danube mouth was directly connected to the Viteaz canyon head (Popescu et al., 2001; Winguth et al., 2000). Hyperpycnal flows are supposed to be responsible for the deposition of a large volume of sediments on the slope and the deep basin (Popescu et al., 2001).

The surface of the fan is covered by a distributary network of meandering channels which represent different phases in the evolution of two distinct channel-levee systems. The Black Sea was a freshwater lake during most sea-level lowstands when fan deposition was active. Thus, it is conceivable that despite the many similarities between the Danube fan and other mud-rich fans, the potentially different conditions of sedimentation could have influenced the characteristics of turbidity flows.

Turbidite sedimentation in the deep northwestern Black Sea was not well-investigated before the 1990s (Konyukhov, 1997; Sorokin et al., 1998; Winguth et al., 1998; Winguth et al., 2000; Wong et al., 1994; Wong et al., 1997).

\section{The western Turkish margin}

Only a few studies have focused on small parts of the central Turkish shelf (Duman et al., 2006), the Sakarya delta and submarine canyon (Algan et al., 2002), and off the Bosporus strait (Aksu et al., 2002). In addition, Terikoglu et al. (2001) and Dondurur et al. (2009) have provided a description of the eastern Turkish margin morphology.

Sediments along the western Turkish margin (Figure 2) are mainly transported by the three major rivers which are the Sakarya River (824 km long and $56504 \mathrm{~km} 2$ watershed) and Filyos River (228 km long and $13156 \mathrm{~km} 2$ watershed) and its nearby smaler Bartın River (100 km long and 2100 $\mathrm{km} 2$ watershed). The Turkish continental margin shows a very narrow shelf (locally $<7 \mathrm{~km}$ ) and a steep continental slope (average from $5^{\circ}$ to $9^{\circ}$ ). The upper slope is incised by numerous canyons, 
down to the bathyal plain at about $1800 \mathrm{~m}$ deep (Duman et al., 2006). Recent important acoustic dataset were acquired by Dokuz Eylul University of Izmir (Turkey) in the frame of an ESFTOPOEUROPE project (SourceSink: www.sourcesink.eu). The data reveal an important canyon system offshore the Sakarya and Filyos rivers, where fan development occur (Algan et al., 2002) (Figures 2 and 3). Indeed, the Southern Turkish Black Sea shelf presents a deep water turbidite system characterized by highly dissected canyons with overbank gullies, numerous slide deposits, stacked turbidity-flow leveed channels and large buried debris lobes in the distal area together with sediment waves (Küçük et al., 2011) (Figure 3).

As our data do not cover the slope and shelf, we used the ETOPO 2 bathymetric charts for additional information along the western Turkish margin, updip of the cores location presented by Lericolais et al. (2012). The transition between the continental slope and the bathyal plain is marked by a very sharp change in slope. Previous studies of the western and the eastern basins mentioned flatrelief morphology and the absence of sedimentary bodies in the deep basin (Rotaru, 2010; Zonenshain and Pichon, 1986). But it is clear that terrigenous sediments are sourced from two large rivers: Filyos and Bartın rivers (Figure 3). This sediment input from land is later transported from the continental shelf to the deep basin most probably by turbidity current activity along the canyon systems (Küçük et al., 2011).

\section{Black Sea Circulation characteristics}

The upper layer waters of the Black Sea are characterized by a predominantly cyclonic, strongly time-dependent and spatially-structured basin-wide circulation. Many details of the circulation system have been explored by numerous hydrographic data and resulting analyses (Chu et al., 2005; Oguz et al., 2002; Oguz et al., 2000; Ozsoy and Unluata, 1997; Ozsoy et al., 1993; Stanev, 2005; Stanev et al., 2001; Stanev et al., 2004).

These analyses reveal a complex, eddy-dominated circulation with different types of structural organizations of water masses within the interior cyclonic cell, the Rim Current jet confined mainly along the abruptly varying continental slope and margin topography around the basin, and a series of 
anticyclonic eddies along onshore side of the Rim Current (Figure 4). The overall basin circulation is primarily forced by the curl of wind stress throughout the year, and further modulated by the seasonal evolution of the surface thermohaline fluxes and mesoscale features arising from the basin internal dynamics. The strong topographic slope together with the coastline configuration of the basin governs the main pattern of the Rim Current system but it modulates seasonally from a more coherent structure in the winter and spring to more turbulent structure in the late summer and autumn. The fresh water discharge from the Danube contributes to buoyancy-driven component of the basin-wide cyclonic circulation system.

Rim Current dynamic structure appear to be the major factor for the shelf-deep basin exchanges. They link coastal biogeochemical processes to those beyond the continental margin, and thus provide a mechanism for two-way transports between near shore and offshore regions. 


\section{Materials and methods}

\section{Acoustic mapping}

The bathymetry and acoustic imagery are provided by a multibeam echosounder (SIMRAD EM1000 and EM300) conducted on the R/V Le Suroit during the 1998 BlaSON and the 2000 BlaSON 2 cruises. Additional multibeam data (Thomson SEAFALCON 11) has been collected on the R/V Marion Dufresne during the 2004 ASSEMBLAGE1 cruise. Seismic lines were also collected during the BlaSON $1 \& 2$ cruises. The very high resolution source was a Chirp sonar single channel, with a frequency sweeping from 1.8 to $5.3 \mathrm{kHz}$. The Multibeam results have been published recently by Lericolais et al. (2012) (Figure 3)

\section{Sedimentary cores}

143 cores (Kullenberg, Calypso, vibro or push cores) were collected during the BlaSON $1 \& 2$ cruises and the ASSEMBLAGE 1 cruise (Figure 5). Physical properties of cores were logged on board with a Geotek Multisensor Core Logger (magnetic susceptibility and gamma density). Thin slabs of 15 mm thick were sampled on each cores and analysed with the SCOPIX X-ray image processing tool (Migeon et al., 1999). Subsamples were taken in order to obtain the carbonate content (using gasometrical calcimetry) and the grain size measurement (using a Malvern MASTERSIZER S). Sedimentary facies have been defined using: (1) photography, visual description, and x-ray imagery; (2) grain size analysis and $\mathrm{CaCO} 3$ content; (3) usual facies classification used in similar environments (Normark et al., 1997; Zaragosi et al., 2000). 


\section{Nd isotopes in marine sediments:}

The use of $\varepsilon_{\mathrm{Nd}}$ isotope systems potentially offers a unique perspective for investigating continental erosion, and informs on sediment origin of the Danube deep sea fan sediments. Samples of different superficial core samples of the core data set of the BlaSON 1 and 2, and Assemblage 1 cruise were analyzed. All sediments were dissolved either in steel-jacketed Teflon bombs, using HF-HClO4 mixtures, or by alkaline fusion (Bayon et al., 2009a). Both procedures ensure complete sample digestion, including the dissolution of highly resistant minerals such as zircons. The leaching procedure used here was realized following the Bayon et al. (Bayon et al., 2009b) protocol and a series of tests were performed using of diluted $\mathrm{HCl}$ and $\mathrm{HNO} 3$ solutions. Hafnium and Rare Earth Elements (REE) concentrations in sediment samples were analyzed using three different ICP-MS (VG Plasmaquad II+, Agilent $7500 \mathrm{~s}$, and Element2). The precision on measured concentrations was typically better than $5 \%$ for $\mathrm{Sm}, \mathrm{Nd}$ and $\mathrm{Hf}$, and better than $10 \%$, in most cases, for Lu. Details on analytical techniques for $\mathrm{Hf}$ and $\mathrm{Nd}$ separation chemistries and isotope measurements can be found elsewhere (Bayon et al., 2006; Chu et al., 2002). Nd isotopic ratios were determined at IFREMER either by TIMS (Finnigan MAT261) or by Neptune MC-ICP-MS.

\section{Results}

\section{Stratigraphic analysis}

Stratigraphic analysis of the north-western margin of the Black Sea using swath bathymetry and high resolution seismic reflection data were used to better understand the base-level variation in the Black Sea during the Late Quaternary (Lericolais et al., 2012; Popescu et al., 2004; Popescu et al., 2001). Submarine canyons, like the Viteaz Canyon (or Danube canyon), are known to evolve due to the influence of sedimentation, slope failure, sediment-gravity flow erosion, and topography (Pratson and Coakley, 1996). The Danube canyon head is distant of more than $100 \mathrm{~km}$ from the coast line at $110 \mathrm{~m}$ of water depth. This canyon is now disconnected from the river (Lericolais et al., 2007a; Popescu et al., 2004) and present highstand river inputs are mostly trapped into the delta. Whilst, high energy and thin particles (mud) surges flow southwards along the coast southward of the Danube 
Delta front mobilized by the northern currents induced by both wind and waves. During lowstand periods the shore line was located between -90 and $-150 \mathrm{~m}$ below the present water level and the Danube canyon drained an important amount of sediments from the shelf to the deep sea. The first and obvious signature of sediment-laden flows inside the canyon is the Danube deep-sea fan and the clear connection of the canyon to the youngest channel-levee system of the Danube fan (Popescu et al., 2004) suggest that the canyon has been directly connected to the high sediment outflow from the Danube River. Numerous channels of paleo-rivers cross cutting the shelf (completely filled at present times) show the connection between the shore and the shelf and the canyon head (Lericolais et al., 2010; Lericolais et al., 2007a; Popescu et al., 2004). The sediment transfer through the canyon is supposed to have been intensely and extremely erosive. The Danube canyon indents the shelf to $26 \mathrm{~km}$ upwards the shelf break and its erosive thalweg continues as an entrenched channel through the Danube Channel-levee system (Popescu et al., 2004). Its morphology presents numerous meanders build within steep flanks up to $30^{\circ}$ often cut through by lateral gullies.

Recent models describe how submarine canyon and deep-water clastic deposits are generated and how their formation can be related to base level fluctuation (Beaubouef and Friedmann, 2000; Beaubouef et al., 1998b; Garfield et al., 2000). Building off of the Exxon Lowstand Fan Model (Vail and Mitchum, 1977) these authors propose a three-stage lowstand model: (1) during early lowstand, falling sea-level induces slope failures caused by pressure-related destabilization of slope mud and erosion by sediment-gravity flows. Continued erosion by turbidity currents, focused into the incipient topographic lows and further deepening and widening by marginal slumping and knick point migration leads to the development of canyon scale slope valleys. These mass wasting processes on the slope are associated with mass transport complex (MTC) deposition (slumps, slides, debris flows) downslope; (2) during middle lowstand, coarse sediment that bypasses the exposed shelf is transported through canyons and slope channels and deposited in distributary channel and lobe complexes (DCLC) within the basin-floor fan beyond the toe of slope; (3) during the late lowstand/early transgression, coarser bed load sediment begins to be trapped on the shelf. Muddier suspended load sediment and more limited sand-grade sediment continues to be transported downslope by lowconcentration turbidity currents. Overbank spillover and flow stripping processes common to low- 
concentration turbidity current channels contributes to the development of levees and leveed channel complexes (LCC) which are prevalent at this time. These develop above and landward of the sand-rich distributary channel and lobe deposits of the basin-floor fan.

The sequence stratigraphic model described above can be related to 4th and 5th order baselevel cycles (Beaubouef and Friedmann, 2000; Beaubouef et al., 1998b). Repetitive seismic facies stacking patterns, consistent with this high-frequency sequence stratigraphic model are observed in the Danube Fan (Figure 6). Low amplitude, chaotic seismic facies are overlain by an extensive high amplitude continuous to semi-continuous seismic facies unit which is inturn overlain by gull-wing seismic facies. These gull-wing facies are interstratfied with thin, areally restricted high amplitude reflection packages (HARPs). These seismic facies associations are comparable to the lowstand depositional succession of muddy mass transport complexes (MTC), sand-rich distributary channel/lobe complexes (DCLC) and leveed channel complexes (LCC) observed in other areas (Beaubouef et al., 1998a; Flood et al., 1994; Pirmez et al., 1998). The fact that most of the Danube deep-sea fan sedimentation took place in fresh water suggests that hyperpicnal processes may have contributed to the generation of the turbidity currents that deposited the leveed channel and distributary channel and lobe deposits.

At least two distinct depositional cycles are observed below the water bottom and are interpreted to be Late Quaternary in age. The uppermost cycle is imaged in figure 6 and given the following depositional interpretation. Gull-wing seismic geometries represent leveed channels which are seen on the water bottom today. Three distinct leveed channels are observed in a land-ward stepping or retrogradational stacking pattern. These are interpreted to have been deposited during the Holocene base-level rise. The relatively thin and restricted high amplitude reflection packages (HARPs) interstratified with the large muddy levees are interpreted to be channel-mouth distributary channel and lobe deposits. These interstratified leveed channel complex and HARP units are stratigraphicaly younger and distinct from the extensive distributary channel/lobe deposits lying beneath them. The later represent the updip portion of a large basin floor fan which extends at least a 150 kilometres further in to the basin beyond the image captured in figure 6. Leveed channels are also seen to cap the distributary channel/lobe deposits of the basin-floor fan in the underlying depositional 
cycle (not shown). In both cycles the levees are better developed in a landward direction. The extensive distributary channel/lobe facies that lie beneath the levees in the upper two depositional cycles represent a much larger sediment volume, and are interpreted to be sand rich based on acoustic impedance properties. The interpreted higher sand content, greater sediment volume and further basinward extent of these facies suggests that they formed during periods of maximum base-level fall when sediment flux and shelf bypass were at a maximum. These deposits most likely formed when the Black Sea was isolated from the global oceans. The chaotic mass transport complexes that underlie the basin-floor distributary channel/lobe complex facies in both depositional cycles lie above erosional unconformities and were deposited in a toe of slope position, pinching out landward of the overlying distributary channel/lobe deposits. These facies are interpreted to be comprised of remobilized slope muds due to seismic geometry and acoustic impedance properties. Mass wasting processes associated with the formation of the Viteaz Canyon during periods of falling base-level are interpreted to have contributed to the development of these chaotic mass transport complexes downslope of the canyon.

\section{Distal part of the Deep Sea Fan}

Seismic reflection profiles in the area (Figures 7 and 8 ) show that this area consists of the distal termination of the Danube turbidite system in the deep basin inter-fingered with distal basin plain deposits. Three distinct seismic units are observed. The lowermost seismic unit (P1) consists of acoustically low amplitude to transparent, sub-horizontal continuous reflectors (Figures 7 and 8). This pattern is often associated with fine-grained distal turbidites (Winguth et al., 2000). The seismic unit P1 is overlain by a thick, chaotic to low amplitude, chaotic to bedded continuous reflectors package (L2). The seismic unit L2 is divided in three sub-units (L2-a, L2-b and L2-c; Figures 7 and 8), interpreted as three individual depositional bodies.

L2-a is a prograding sub-unit, mainly composed of chaotic to continuous bedded reflectors of generally high amplitude. The unit downlaps P3 (Figure 8).

L2-b and L2-c are retrograding sub-units showing chaotic to poor-continuous bedded reflectors, where small-size filled channel-like features can be recognized (Figure 8). 
Seismic unit P3 onlaps L2 and shows the same acoustically pattern than P1 (i. e. subhorizontal, low-amplitude to transparent echo-facies). In this unit, several echo-facies variations are recognized, although they could not be interpreted in terms of subunits due to the lack of internal major unconformities. The sedimentary architecture of the basin plain in this area suggests that two sources of sediment are inter-fingering at $2200 \mathrm{~m}$ water depth. A northern source is characterized by the stacking of $>50 \mathrm{~ms}$ thick (TWT) distal lobes; a southern source onlaps these lobes and is interpreted as thick distal deposits from the Turkish margin, out of the DTS influence (Figure 8).

\section{Use of trace element analyses}

\section{Neodymium budget}

The neodymium $(\mathrm{Nd})$ isotopic compositions of terrestrial rocks and minerals are variable over a range of scales and $\mathrm{Nd}$ isotopic composition is related to radioactive decay. Natural variability in $\mathrm{Nd}$ isotopic compositions is expressed as ratios of the abundances of the radiogenic daughter isotope to a suitable non-radiogenic isotope of the same element. The abundance of $143 \mathrm{Nd}$ is rationed to that of (non-radiogenic) $144 \mathrm{Nd}$. The observed natural variability in $\mathrm{Nd}$ isotopic composition is small, and usually expressed in $\varepsilon_{\mathrm{Nd}}$ notation, which is deviation from the Chondritic Uniform Reservoir (CHUR) in parts per 10,000 as follows:

$$
\varepsilon_{\mathrm{Nd}}=\frac{{ }^{143} \mathrm{Nd} /{ }^{144} \mathrm{Nd}_{\text {sample }}-{ }^{143} \mathrm{Nd} /{ }^{144} \mathrm{Nd}_{\text {CHUR }}}{{ }^{143} \mathrm{Nd} /{ }^{144} \mathrm{Nd}_{C H U R}} \times 10^{4}
$$

$\varepsilon_{\mathrm{Nd}}$ composition is heterogeneous in the continent, and these variations are redistributed into the ocean via lithogenic inputs (Goldstein and Hemming, 2003). The properties of $\mathrm{Nd}$ as a oceanic water mass tracer have been recently extensively studied (Arsouze et al., 2007; Bayon et al., 2009b; Bayon et al., 2012; Bayon et al., 2006; Jeandel et al., 2007; Jones et al., 2012; Lacan et al., 2012). The oceanic $\varepsilon_{\mathrm{Nd}}$ distribution is governed by sources and sinks alongside ocean circulation. Neodymium isotope composition $\left(\varepsilon_{\mathrm{Nd}}\right.$ ) against $\mathrm{Nd}$ concentration (shown as $1 / \mathrm{Nd}$ pmol/l) is one of the way to represent the potential distinction in between the sources of sediment recovered $\mathrm{n}$ the studied cores (Figure 9). 


\section{Sediment origin}

Three different provinces are recognized as being source of the surface Black Sea sediments.

\section{Sea of Marmara}

Rivers flowing into the Marmara Sea are few and provide a small amount off sediments. Sediments accumulated in the Marmara basin are probably relics of former old early to middle Cenozoic sedimentation issued from the Anatolia and reworked by the flows in between the Mediterranean Sea and the Black Sea.

\section{Black Sea south western province}

To understand the sediment repartition in the Black Sea, it is important to consider the present day sea surface circulation (cf. Figure 9).

The South-west current flowing along the Romanian coast and the Bulgarian ones permit to explain the link existing between the Danube sediment types and the south-western Black Sea sediment types. The sediment provided by the Danube delta are transported by this along shore drift current to the south-west of the Black Sea. Nevertheless this study is not précised enough to decipher the contribution of the small Bulgarian rivers sourced from the Balkan Mountains as the Neodynium signature is rather similar to the one sourced from the Danube (Moores et al., 1998; Tockner et al., 2009).

\section{Black Sea central province}

This province is the most delicate to interpret and of course the one of interest for this study. Two sedimentary poles can be distinguished on Figure $9\left(\varepsilon_{\mathrm{Nd}}\right.$ against $\left.\mathrm{Nd}\right)$ : the Marmara pole in pink on the figure and the pole south-western Black Sea (province SO) in blue on the figure.

The yellow dots on the figure would let consider that the sediment provenance of the central province of the Black Sea would be a blend in between the two previous poles (Danube and Marmara). Nevertheless, it has been demonstrated that there is not such important sediment transport of sediment at the Bosporus outlet (Algan et al., 2001; Lamy et al., 2006a; Lericolais et al., 2002; Okay et al., 2011). This leads to consider a probable Anatolian origin for the yellow dots. 
The Anatolian rivers contribute to the detritic sedimentation on the southern part of the Black Sea. The Sakarya river is the third longest river of Turkey flowing into the Black Sea $(8,6 \times 106$ tons/year, over 3 times more than the Dniepr) (Algan et al., 2002). Sediments provided by the Sakarya are added to the western gyre in the middle of the central province.

\section{Discussion}

Evidence for earthquake-induced, unchannelized gravity currents sourced from the Turkish margin

The sedimentary units P1 and P3 (i. e. deposits originated from the Turkish margin for P3) consist mainly $(>80 \%)$ of thick mud turbidites associated with thick transparent units visible on the chirp profiles (Figures 7 and 8). Such sequences showing thick structureless homogeneous "Te" muds have already been described along deep basin plains such as in the Mediterranean (Kastens and Cita, 1981; Rothwell et al., 2000; Stanley, 1983), the NW African basin (Wynn and Stow, 2002), and the Oman basin (Bourget et al., 2011). Presences of transitional sandy-muddy and muddy debrites are common in distal fan settings and are often transitional and therefore related to underlying turbidites (Hickson and Lowe, 2002). These deposits are usually resulting from poorly channelized to unchannelized, large volume turbidity currents (Bourget et al., 2011; Wynn and Stow, 2002). Some authors proposed that the unusual thickness of the muddy "Te" could result from several, successive surges occurring in a voluminous, mud-rich turbidity current rather a discrete gravity flow (Lowe, 1982; Tripsanas et al., 2004; Wynn and Stow, 2002). A possible explanation is that these thick muddy turbidite deposits would be due to successive mass-wasting along the continental slope (Bourget et al., 2010; Wynn and Stow, 2002). In the Makran (a semi-desert coastal strip along the coast of the Arabian Sea and the Gulf of Oman) active margin, these processes and the thick distal deposits that they produce have been linked to major earthquakes (Bourget et al., 2010).

The Turkish margin is bordered by the highly active North Anatolian Fault (Figure 2). Previous studies in the Eastern Black Sea have shown that the activity of the North Anatolian fault is also evidenced offshore (Cifci et al., 2003; Dondurur and Cifci, 2007; Rangin et al., 2002) and suggested a minor impact of the N.A.F. on the triggering of mass wasting processes along the 
continental slope based on the relative size of the slide scars. Inversely the observations of a dense distribution of slump-scars along the margin (Cifci et al., 2003; Dondurur and Cifci, 2009) support the hypothesis that submarine landslides as an important mechanism for triggering turbiditic flows. Recent earthquake distribution from USGS (http://earthquake.usgs.gov/earthquakes/world/turkey/density.php) shows that a portion of the Turkish margin located upward of our cores is particularly active. Earthquakes could generate the destabilize small portions of the shelf-edge and continental slope and form repeated mass-wasting events, possibly generating successive tsunamis waves and gravity flows (Bourget et al., 2011; Bourget et al., 2010; Talling et al., 2007; Wynn and Stow, 2002). Several historic tsunamis have been reported along the Black Sea Turkish coast (Altinok et al., 2011; Pelinovsky, 1999) and have been triggered by the activity of the North Anatolian strike slip fault (Figure 2). Conversely the thick-mud turbidites observed in the deep basin plain could correspond to the "homogenites" studied by Kastens and Cita (1981) or the "unifites" of Stanley (1983). Reeder et al. (1998) restrict the term "homogenite" to deposits having an homogeneous nature and related to the expression of a unique event with a definite stratigraphic position (Cita et al., 1996). Such "homogenites" have also been described in deep basins of Marmara Sea (Beck et al., 2007) or as the LGM Black Sea, in lakes (Chapron et al., 2006; Chapron et al., 1999). Cita et al. (1996) proposed that after a tsunami, resuspended sediments form a turbulent particle cloud that settled out gradually. In the Marmara Sea as well as in lake environments, such homogeneous deposits have been attributed to "seiche" effect (i. e. lake water oscillation in response to earthquake-induced mass wasting processes). The water column oscillation is generally related to seismic activity (Cita et al., 1984), directly (by direct seismic wave propagation) or indirectly (earthquake induced mass wasting processes such as slides or slumps). If "seiche" effects are commonly generated in confined basin such as lakes or the enclosed Marmara Sea (Beck et al., 2007), the Black Sea basin, which extends on $432,000 \mathrm{~km}^{2}$, appears to be a wide undergo "seiche" wave generation.

Previous work (Popescu et al., 2001; Winguth et al., 2000) clearly concluded that the northwestern rivers stop providing sediments to either the Danube deep sea fan and to the DnieprDniestr deep sea fan after the LGM. From the dates obtained in the studied cores, informing we can 
hat P3 was deposited after LGM although the Danube sediments were not reaching the deep basin. Therefore, we can conclude that the thick mud turbidites observed in the deep basin sediments, especially for P3, are sourced from the Turkish margin and are the result of synchronous mass-wasting events along the slope, such as observed along the Makran (coast of the Arabian Sea and the Gulf of Oman) active margin (Bourget et al., 2011; Bourget et al., 2010). Such events could be generated during earthquakes related to the N.A.F activity.

The nature of the distal deposits and the unusual amount of mud in the turbidites are also likely related to the physiography of the margin. Indeed the loss in flow velocity induced by the sharp change in gradient at the break of slope and the very low slope gradient $\left(<0,1^{\circ}\right)$ in the basin plain lead to rapid deposition of coarser sediments, with only the finer-grained portion of the initial sediment load being transported to the basin. In addition, abrupt break of slope such as the one observed along the Turkish margin can limit the downslope formation of submarine channel and thus enhance the generation of unchannelized gravity currents in the basin plain (Bourget et al., 2011). The general lowamplitude and acoustically "transparent" echo-facies observed in the sediments sourced from the Turkish margin (Figures 7 and 8) are typically thick, mud-rich turbidites (Beck et al., 2007; Chapron et al., 1999; Cita et al., 1996; McHugh et al., 2006). The thickness of the clayey layers finally requires an abundant source of fine-grained sediments in the catchment area and shelf (Bourget et al., 2010), which is the case along the Turkish shelf (Duman et al., 2006).

As after the LGM, it is known that the Danube deep sea fan does not receive any sediment from the northwestern rivers and according to the regional seismic activity, it comes that earthquakes may be the more common initial triggering mechanism of the mass-wasting inducing thick mud turbidites constituting P3 sequence, at least on this portion of the Turkish margin. Off the major Anatolian rivers, i. e. off the Sakarya and Filyos, rivers, a small-size fan development may occur in the proximal part (e.g. Algan et al., 2002; Dondurur and Cifci, 2007), possibly built by recurrent hyperpycnal currents (that could exit in the semi-freshwater Black Sea during sea level low-stand). Sediment overloading on the steep slope or gas hydrates (classically observed onto the Turkish shelf; Cifci et al., 2003) constitute additional triggering mechanisms which would explain the occurrence of typical distal turbidites also recovered in our cores. 


\section{Quantification of climatic, eustatic and tectonic forcing on the gravity sedimentation in the western Black Sea basin.}

The last concordant sequence is onlaping the distal deposits of the Danube Turbidite System at $2200 \mathrm{~m}$ of water depth. During glacial times, the gravity sedimentation from the Turkish margin appears to be controlled by both regional tectonics and climatic forcing (i.e. enhanced sediment supply during deglacial and unusual wet periods). At a smaller scale, past work in the area has shown that the sediment supplied onto the shelf is controlled by climate at Eastern Mediterranean (Lamy et al., 2006b). Due to their very short source-to-sink sediment transport route, active margins are indeed more likely to be influenced by high-frequency climate changes and the later are likely to be recorded even in the distal most turbidite deposits (Bourget et al., 2010). Tectonics, sea-level and climate changes are actively influencing the transfer of sediments along active margins and equally influence the stratigraphic architecture of the turbidite system at relatively short time-scales $(<100 \mathrm{ka})$.

Conversely, the north-western margin shows the development of medium-size, mud-rich turbidite systems (i. e. the Danube and Dniepr deep sea fans). Here the sediments are transported to the deep basin from a point source. The flows are channelized, confined (Winguth et al., 2000), typically depleted in fine sediments along the slope and in the bathyal plain until they reach lobe deposition at their most distal part. During the LGM, the Black Sea was a lowstand lacustrine body and the Danube deep sea fan was functioning. The direct connexion between rivers and canyons suggest a climate driven sedimentation at high resolution along the north-western shelf (Kwiecien et al., 2009). However at the scale of the Late Quaternary, the Danube Turbidite System activity is mainly control by lake level fluctuations and is inactive during the Holocene when a large delta progrades at the river mouth onto a wide shelf (Popescu et al., 2004; Popescu et al., 2001). In general, our results illustrate the multi-scale forcing variability on the western Black Sea sedimentation, from the north-western passive margin controlled by lake level fluctuations and glacial cycles, to the south-western margin on which tectonics shaped a typical ramp system and actively control the source-to-sink sedimentation.

\section{Conclusion}


Our study focuses on the deep-water architecture of the western Black Sea deep basin and its sedimentological characteristics. The Late Quaternary Danube turbidite system (to the North) displays a well-constructed morphology, underlined by at least six channel-levee systems associated with distal lobe complexes, reaching the $2200 \mathrm{~m}$ isobaths. The adjacent deposits, onlaping the Danube Turbidite System distal lobes in the deep basin, show a linear, drape-like morphology, represented by thick continuous reflections on seismic profiles. They generally consist of distal turbidite deposits supplied from the Turkish margin. Most of these turbidite sequences show a thick upper unit composed by homogeneous clastic clays, thus forming thick mud turbidites. Following previous work in similar basin settings, we interpret these facies to result from large volume unchannelized turbidity currents generated by successive mass-wasting events. The abrupt break of slope at the bathyal plain transition enhances the rapid deposition of coarse-grained material and limits channel development in the bathyal plain. We relate the origin of these deposits with the very high seismic activity of the North Anatolian Fault on the Turkish margin. The Neodymium analyses of the sediment provenance are in accordance with this observation.

Our study is based on data at the boundary of influence of the Danube Turbidite System and the Turkish margin, and provides a new record of the changes in sedimentary supply, climate and sea level that occurred in the Black Sea region since the last $\sim 25 \mathrm{ka}$. The deep basin deposits bear the record of the Late Quaternary paleoenvironmental changes (Lericolais et al., 2012). The Last Glacial Maximum Period ( 25 to $18 \mathrm{ka} \mathrm{BP}$ ) was characterized by an important and relatively stable sediment supply with sediment transferred to the deep basin from both the northern Danube Turbidite System and the southern Turkish margin. The relative stable LGM period was followed by an increase of sediment transport to the deep basin, which is locally illustrated by progradation of lobe deposits from the Danube turbidite system in the deep basin, downlaping the Turkish deposits. Influx of meltwater to the Black Sea resulted in a early highstand sea level. The following Bolling-Allerod Preboreal warm period and the Younger Dryas cold event have experienced alternative sea level lowstands and highstands that are not clearly underlain in the deep basin sediments (Lericolais et al., 2012). The onset of sea-level highstand after the Holocene marine invasion ( 9 kyr BP) (Lericolais et al., 2012; 
Soulet et al., 2011) induced the end of the activity of the Danube Turbidite System whereas the gravity supply from the Turkish margin remained active throughout the Holocene.

We conclude that the western Black Sea basin constitute an asymmetric subsident basin bordered by a northern passive margin with confined mid-size, mud-rich turbidite systems, and a southern turbidite ramp built in a tectonically active margin setting.

\section{Acknowledgements}

The BlaSON $(1 \& 2)$ and the ASSEMBLAGE Cruises were performed within the framework of French-Romanian joint project and the European ASSEMBLAGE project (EVK3-CT-2002-00090). The authors are very grateful to J. Normand and L. Maltese (data processing), E. Le Drezen, N. Frumholtz, A. Normand and D. Pierre (imagery and bathymetry data), M.Rovere, G. Floch and R. Kerbrat (core logistics) from IFREMER. We wish to thank J. St Paul, G. Chabaud, D. Poirier and B. Martin from Bordeaux University for their laboratory assistance. 


\section{References}

Aksu, A. E., C. Yaltirak, and R. N. Hiscott, 2002, Quaternary paleoclimatic-paleoceanographic and tectonic evolution of the Marmara Sea and environs: Marine Geology, v. 190, p. 9-18.

Algan, O., N. Çagatay, A. L. Chepalyga, D. Ongan, C. Eastoe, and E. Gökasan, 2001, Stratigraphy of the sediment infill in Bosphorus Strait: water exchange between the Black and Mediterranean Seas during the last glacial-Holocene: Geo-Marine Letters, v. 20, p. 209-218.

Algan, O., E. Gokasan, C. Gazioglu, Z. Y. Yucel, B. Alpar, C. Guneysu, E. Kirci, S. Demirel, E. Sari, and D. Ongan, 2002, A high-resolution seismic study in Sakarya Delta and Submarine Canyon, southern Black Sea shelf: Continental Shelf Research, v. 22, p. 1511-1527.

Altinok, Y., B. Alpar, N. Ozer, and H. Aykurt, 2011, Revision of the tsunami catalogue affecting Turkish coasts and surrounding regions: Natural Hazards and Earth System Sciences, v. 11, p. 273-291.

Arkhipov, S. A., J. Ehlers, R. G. Johnson, and H. E. J. Wright, 1995, Glacial drainage towards the Mediterranean during the middle and late Pleistocene.: Boreas, v. 24, p. 196-206.

Arsouze, T., J. C. Dutay, F. Lacan, and C. Jeandel, 2007, Modeling the neodymium isotopic composition with a global ocean circulation model: Chemical Geology, v. 239, p. 165-177.

Bayon, G., J. A. Barrat, J. Etoubleau, M. Benoit, C. Bollinger, and S. Révillon, 2009a, Determination of Rare Earth Elements, Sc, Y, Zr, Ba, Hf and Th in Geological Samples by ICP-MS after Tm Addition and Alkaline Fusion: Geostandards and Geoanalytical Research, v. 33, p. 51-62.

Bayon, G., K. W. Burton, G. Soulet, N. Vigier, B. Dennielou, J. Etoubleau, E. Ponzevera, C. R. German, and R. W. Nesbitt, 2009b, Hf and Nd isotopes in marine sediments: Constraints on global silicate weathering: Earth and Planetary Science Letters, v. 277, p. 318-326.

Bayon, G., B. Dennielou, J. Etoubleau, E. Ponzevera, S. Toucanne, and S. Bermell, 2012, Intensifying weathering and land use in Iron Age Central Africa: Science, v. 335, p. 1219-22.

Bayon, G., N. Vigier, K. W. Burton, A. Brenot, J. Carignan, J. Etoubleau, and N.-C. Chu, 2006, The control of weathering processes on riverine and seawater hafnium isotope ratios: Geology p. 433-436.

Beaubouef, R. T., and S. J. Friedmann, 2000, High resolution seismic/sequence stratigraphic framework for the evolution of Pleistocene of intra-slope basins, western Gulf of Mexico : Depositional models and reservoir analogs: GCSSEPM Foundation 20th Annual Research Conference, p. 40-60.

Beaubouef, R. T., S. J. Friedmann, and B. W. Alwin, 1998a, High resolution seismic/sequence stratigraphy of intra-slope basins, western Gulf of Mexico: AAPG International Conference, p. 404-405.

Beaubouef, R. T., T. R. Garfield, and F. J. Goulding, 1998b, Seismic stratigraphy of depositional sequences; high resolution images from a passive margin slope setting, offshore West Africa. In: AAPG international conference and exhibition; abstracts: AAPG Bulletin, v. 82, p. 1890.

Beck, C., B. Mercier de Lepinay, J.-L. Schneider, M. Cremer, N. Cagatay, E. Wendenbaum, S. Boutareaud, G. Menot, S. Schmidt, O. Weber, K. Eris, R. Armijo, B. Meyer, N. Pondard, M.A. Gutscher, J. L. Turon, L. Labeyrie, E. Cortijo, Y. Gallet, H. Bouquerel, N. Gorur, A. Gervais, M. H. Castera, L. Londeix, A. de Resseguier, and A. Jaouen, 2007, Late Quaternary co-seismic sedimentation in the Sea of Marmara's deep basins: Sedimentary Geology, v. 199, p. 65-89.

Bourget, J., S. Zaragosi, N. Ellouz-Zimmermann, N. Mouchot, T. Garlan, J. L. Schneider, V. Lanfumey, and S. Lallemant, 2011, Turbidite system architecture and sedimentary processes along topographically complex slopes: the Makran convergent margin: Sedimentology, v. 58, p. 376-406.

Bourget, J., S. Zaragosi, S. Ellouz-Zimmermann, E. Ducassou, M. A. Prins, T. Garlan, V. Lanfumey, J. L. Schneider, P. Rouillard, and J. Giraudeau, 2010, Highstand vs. lowstand turbidite system growth in the Makran active margin: Imprints of high-frequency external controls on sediment delivery mechanisms to deep water systems: Marine Geology, v. 274, p. 187-208. 
Chapron, E., D. Ariztegui, S. Mulsow, G. Villarosa, M. Pino, V. Outes, E. Juvignie, and E. Crivelli, 2006, Impact of the 1960 major subduction earthquake in Northern Patagonia (Chile, Argentina): Quaternary International, v. 158, p. 58-71.

Chapron, E., C. Beck, M. Pourchet, and J. F. Deconinck, 1999, 1822 earthquake-triggered homogenite in Lake Le Bourget (NW Alps): Terra Nova, v. 11, p. 86-92.

Chu, N.-C., R. N. Taylor, V. Chavagnac, R. W. Nesbitt, R. M. Boella, J. A. Milton, C. R. German, G. Bayon, and K. W. Burton, 2002, Hafnium isotope ratio analysis using multi-collector inductively coupled plasma mass spectrometry: an evaluation of isobaric interference corrections: J. Anal. Atom. Spec., v. 4, p. 1567-157.

Chu, P. C., L. M. Ivanov, and T. M. Margolina, 2005, Seasonal variability of the Black Sea chlorophyll-a concentration: Journal Marine Systems, v. 56, p. 243-261.

Cifci, G., D. Dondurur, and M. Ergun, 2003, Deep and shallow structures of large pockmarks in the Turkish shelf, eastern Black Sea.; Contributions from the combined 7th international conference on Gas in marine sediments and the NATO advanced research workshop on Seafloor hydrocarbon seeps: Geo-Marine Letters, v. 23, p. 311-322.

Cita, M. B., A. Camerlenghi, A. Kastens Kim, and F. W. McCoy, 1984, New findings of Bronze Age homogenites in the Ionian Sea; geodynamic implications for the Mediterranean: Marine Geology, v. 55, p. 47-62.

Cita, M. B., A. Camerlenghi, and B. Rimoldi, 1996, Deep-sea tsunami deposits in the eastern Mediterranean: New evidence and depositional models: Sedimentary Geology, v. 104, p. 155173.

Cloetingh, S., a., p., 1., P. A. Ziegler, P. J. F. Bogaard, P. A. M. Andriessen, I. M. Artemieva, G. Bada, R. T. Balen, F. Beekman, Z. Ben-Avraham, J. P. Brun, H. P. Bunge, E. B. Burov, R. Carbonell, C. Facenna, A. Friedrich, J. Gallart, A. G. Green, O. Heidbach, A. G. Jones, L. Matenco, J. Mosar, O. Oncken, C. Pascal, G. Peters, S. Sliaupa, A. Soesoo, W. Spakman, R. A. Stephenson, H. Thybo, T. Torsvik, G. de Vicente, F. Wenzel, and M. J. R. Wortel, 2007, TOPO-EUROPE: The geoscience of coupled deep Earth-surface processes: Global and Planetary Change, v. 58, p. 1-118.

Dondurur, D., and G. Cifci, 2007, Acoustic structure and recent sediment transport processes on the continental slope of Yesilirmak River fan, Eastern Black Sea: Marine Geology, v. 237, p. 3753.

Dondurur, D., and G. Cifci, 2009, Anomalous Strong Reflections on High Resolution Seismic Data from the Turkish Shelf of the Eastern Black Sea: Possible Indicators of Shallow Hydrogen Sulphide-Rich Gas Hydrate Layers: Turkish Journal of Earth Sciences, v. 18, p. 299-313.

Duman, M., S. Duman, T. W. Lyons, M. AvcI, E. Izdar, and E. Demirkurt, 2006, Geochemistry and sedimentology of shelf and upper slope sediments of the south-central Black Sea: Marine Geology, v. 227, p. 51-65.

Flood, R. D., D. J. W. Piper, and A. Klaus, 1994, Amazon deep-sea fan: JOIDES Journal, v. 20, p. $32-$ 34.

Flood, R. D., W. B. F. Ryan, H. K. Wong, N. Panin, G. Lericolais, S. Berné, C. Dinu, and K. M. Shimkus, 1999, Deep sea drilling programme in the Black Sea. Climate change and sedimentation in the Black Sea region in response to Pleistocene climatic cycles : a letter of intent: Workshop on Mediterranean scientific drilling prospectives - 10-12 June 1999, p. 4752.

Garfield, T. R., J. F. Sarg, D. K. Sickafoose, and R. T. Beaubouef, 2000, High resolution Sequence Stratigraphy: A tool for improved reservoir delineation in passive margin settings--Examples from the divergent margins of the South Atlantic Salt Basin: 31st International Geological Congress, p. 197.

Gillet, H., G. Lericolais, and J.-P. Réhault, 2007, Messinian event in the Black Sea: evidence of the erosional surface: Marine Geol., v. 244, p. 142-165.

Goldstein, S. L., and S. R. Hemming, 2003, Long lived isotopic tracers in oceanography, paleoceanography, and ice sheet dynamics, in H. Elderfield, ed., Treatise on Geochemistry: Amsterdam, Elsevier Pergamon press, p. chapter 6.17.

Hickson, T. A., and D. R. Lowe, 2002, Facies architecture of a submarine fan channel-levee complex: The Juniper Ridge Conglomerate, Coalinga, California: Sedimentology, v. 49, p. 335-362. 
Jeandel, C., T. Arsouze, F. Lacan, P. TÃ $\odot$ chinÃ $\odot$, and J. C. Dutay, 2007, Isotopic Nd compositions and concentrations of the lithogenic inputs into the ocean: A compilation, with an emphasis on the margins: Chemical Geology, v. 239, p. 156-164.

Jones, M. T., C. R. Pearce, C. Jeandel, S. u. R. Gislason, E. S. Eiriksdottir, V. Mavromatis, and E. H. Oelkers, 2012, Riverine particulate material dissolution as a significant flux of strontium to the oceans: Earth and Planetary Science Letters, v. 355-356, p. 51-59.

Kastens, K. A., and M. B. Cita, 1981, Tsunami-Induced Sediment Transport in the Abyssal Mediterranean-Sea: Geological Society of America Bulletin, v. 92, p. 845-857.

Konyukhov, A. I., 1997, The Danube submarine fan: specific features of the structure and sediment accumulation.: Lithology and Mineral Resources, v. 32, p. 197-207.

Küçük, H. M., D. Dondurur, and G. Çifçi, 2011, Seabed Morphology and Erosional Processes and Their Relations with Possible Gas Hydrate Dissociations in the Western Black Sea: 7th TOPO-EUROPE Workshop.

Kwiecien, O., H. W. Arz, F. Lamy, B. Plessen, A. Bahr, and G. H. Haug, 2009, North Atlantic control on precipitation pattern in the eastern Mediterranean/Black Sea region during the last glacial: Quaternary Research, v. 71, p. 375-384.

Lacan, F., K. Tachikawa, and C. Jeandel, 2012, Neodymium isotopic composition of the oceans: A compilation of seawater data: Chemical Geology, v. 300-301, p. 177-184.

Lamy, F., H. W. Arz, G. C. Bond, A. Bahr, and J. Patzold, 2006a, Paleo-evolution of the Black Sea watershed: sea level and water transport through the Bosporus Straits as an indicator of the Lateglacial-Holocene transition: Paleoceanography, v. 26, p. 631-644.

Lamy, F., H. W. Arz, G. C. Bond, A. Bahr, and J. Pätzold, 2006b, Multicentennial-scale hydrological changes in the Black Sea and northern Red Sea during the Holocene and the Arctic/North Atlantic Oscillation: Paleoceanography, v. 21, p. PA1008.

Lericolais, G., J. Bourget, I. Popescu, P. Jermannaud, T. Mulder, S. Jorry, and N. Panin, 2012, Late Quaternary deep-sea sedimentation in the western Black Sea: New insights from recent coring and seismic data in the deep basin: Global and Planetary Change.

Lericolais, G., F. Guichard, C. Morigi, A. Minereau, I. Popescu, and S. Radan, 2010, A post Younger Dryas Black Sea regression identified from sequence stratigraphy correlated to core analysis and dating: Quaternary International, v. 225, p. 199-209.

Lericolais, G., F. Guichard, C. Morigi, I. Popescu, C. Bulois, H. Gillet, and W. B. F. Ryan, 2011, Assessment of Black Sea water-level fluctuations since the Last Glacial Maximum, in I. Buynevich, V. Yanko-Hombach, A. S. Gilbert, and R. E. Martin, eds., Geology and Geoarchaeology of the Black Sea Region: Beyond the Flood Hypothesis, v. 473: Boulder, Colorado, The Geological Society of America, p. 33-50.

Lericolais, G., E. Le Drezen, H. Nouzé, H. Gillet, M. Ergun, G. Cifci, M. Avci, D. Dondurur, and S. Okay, 2002, Recent canyon heads evidenced at the Bosphorus outlet: EOS transactions, AGU Fall Meet. Suppl., v. 83, p. Abstract PP71B-0409.

Lericolais, G., I. Popescu, F. Guichard, and S. M. Popescu, 2007a, A Black Sea lowstand at 8500 yr B.P. indicated by a relict coastal dune system at a depth of $90 \mathrm{~m}$ below sea level, in J. Harff, W. W. Hay, and D. M. Tetzlaff, eds., Coastline Changes: Interrelation of Climate and Geological Processes, v. SPE 426, GSA Books; Allen Press, Inc., Special Paper 426, p. 171 188.

Lericolais, G., I. Popescu, F. Guichard, S. M. Popescu, and L. Manolakakis, 2007b, Water-level fluctuations in the Black Sea since the Last Glacial Maximum, in V. Yanko-Hombach, A. S. Gilbert, N. Panin, and P. M. Dolukhanov, eds., The Black Sea Flood Question: Changes in Coastline, Climate, and Human Settlement, v. 28, Springer, p. 437-452.

Lowe, D. R., 1982, Sediment Gravity Flows .2. Depositional Models with Special Reference to the Deposits of High-Density Turbidity Currents: Journal of Sedimentary Petrology, v. 52, p. 279298.

Major, C., S. L. Goldstein, W. Ryan, A. Piotrowski, and G. Lericolais, 2002a, Climate change in the black sea region through termination I from $\mathrm{Sr}$ and $\mathrm{O}$ isotopes: Geochimica Et Cosmochimica Acta, v. 66, p. A476-A476. 
Major, C. O., S. L. Goldstein, W. B. F. Ryan, G. Lericolais, A. M. Piotrowski, and I. Hajdas, 2006, The co-evolution of Black Sea level and composition through the last deglaciation and its paleoclimatic significance: Quaternary Science Reviews, v. 25, p. 2031-2047.

Major, C. O., W. B. F. Ryan, G. Lericolais, and I. Hajdas, 2002b, Constraints on Black Sea outflow to the Sea of Marmara during the last glacial-interglacial transition: Marine Geology, v. 190, p. 19-34.

Matenco, L., P. Andriessen, B. Fügenschuh, L. Schrott, and t. S. S. Team, 2011, Source to Sink systems: Quantification of mass transfer from mountain ranges to active sedimentary basins in the Danube basin system: EGU General Assembly 2011.

McHugh, C. M. G., L. Seeber, M. H. Cormier, J. Dutton, N. Cagatay, A. Polonia, W. B. F. Ryan, and N. Gorur, 2006, Submarine earthquake geology along the North Anatolia Fault in the Marmara Sea, Turkey: A model for transform basin sedimentation: Earth and Planetary Science Letters, v. 248, p. 661-684.

Migeon, S., O. Weber, J. C. Faugeres, and J. Saint-Paul, 1999, SCOPIX: A new X-ray imaging system for care analysis: Geo-Marine Letters, v. 18, p. 251-255.

Moores, E. M., R. W. Fairbridge, and W. Rhodes, 1998, Encyclopedia of European and Asian Regional Geology, v. 27, Springer, 804 p.

Normark, W. R., J. E. Damuth, and t. L. S. Group, 1997, Sedimentary facies and associated depositional elements of the Amazon fan, in R. D. Flood, D. J. W. Piper, A. Klaus, and L. C. Peterson, eds., Proceedings of the Ocean Drilling Project, Scientific Results, v. 155: Austin, Tx, p. 611-651.

Oguz, T., A. G. Deshpande, and P. Malanotte-Rizzoli, 2002, The role of mesoscale processes controlling biological variability in the Black Sea coastal waters: inferences from SeaWIFSderived surface chlorophyll field: Continental Shelf Research, v. 22, p. 1477-1492.

Oguz, T., W. Ducklow Hugh, and P. Malanotte Rizzoli, 2000, Modeling distinct vertical biogeochemical structure of the Black Sea; dynamical coupling of the oxic, suboxic, and anoxic layers: Global Biogeochemical Cycles, v. 14, p. Pages 1331-1352.

Okay, S., B. Jupinet, G. Lericolais, G. Cifci, and C. Morigi, 2011, Morphological and Stratigraphic Investigation of a Holocene Subaqueous Shelf Fan, North of the Istanbul Strait in the Black Sea: Turkish Journal of Earth Sciences, v. 20, p. 287-305.

Ozsoy, E., and U. Unluata, 1997, Oceanography of the Black Sea; a review of some recent results: Earth-Science Reviews, v. 42, p. Pages 231-272.

Ozsoy, E., U. Unluata, and Z. Top, 1993, The evolution of Mediterranean water in the Black Sea; interior mixing and material transport by double diffusive intrusions: Progress in Oceanography, v. 31, p. Pages 275-320.

Panin, N., 1997, On the geomorphologic and geologic evolution of the river Danube: Black Sea interaction zone: Geo-Eco-Marina, v. 2, p. 31-40.

Pelinovsky, E., 1999, Preliminary estimates of tsunami danger for the northern part of the Black Sea: Physics and Chemistry of the Earth Part a-Solid Earth and Geodesy, v. 24, p. 175-178.

Pirmez, C., R. D. Flood, and G. Ercilla, 1998, Contrasting submarine fans off the Amazon and Magdalena rivers: AAPG international conference and exhibition; abstracts, p. 1952.

Popescu, I., M. De Batist, G. Lericolais, H. Nouze, J. Poort, N. Panin, W. Versteeg, and H. Gillet, 2006, Multiple bottom-simulating reflections in the Black Sea: Potential proxies of past climate conditions: Marine Geology, v. 227, p. 163-176.

Popescu, I., G. Lericolais, N. Panin, A. Normand, C. Dinu, and E. Le Drezen, 2004, The Danube Submarine Canyon (Black Sea): morphology and sedimentary processes: Marine Geol., v. 206, p. 249-265.

Popescu, I., G. Lericolais, N. Panin, H. K. Wong, and L. Droz, 2001, Late Quaternary channel avulsions on the Danube deep-sea fan: Marine Geology, v. 179, p. 25-37.

Pratson, L. F., and B. J. Coakley, 1996, A model for the headward erosion of submarine canyons induced by downslope-eroding sediment flows: Geological Society of America Bulletin, v. 108 , p. 225-234.

Rangin, C., A. G. Bader, G. Pascal, B. Ecevitoglu, and N. Gorur, 2002, Deep structure of the Mid Black Sea High (offshore Turkey) imaged by multi-channel seismic survey (BLACKSIS cruise),: Marine Geology, v. 182, p. 265-278. 
Reeder, M., R. G. Rothwell, D. A. V. Stow, G. Kahler, and N. H. Kenyon, 1998, Turbidite flux, architecture and chemostratigraphic of the Herodotus Basin, Levantine Sea, SE Mediterranean, in M. S. Stocker, D. Evans, and A. Cramp, eds., Geological Processes on Continental Margins, v. 129 London, Geol. Soc, London, Spec. Publ. , p. 19-41.

Robinson, A. G., G. Spadini, S. Cloetingh, and J. Rudat, 1995, Stratigraphic evolution of the Black Sea: inferences from basin modelling: Marine and Petroleum Geology, v. 12, p. 821-835.

Ross, D. A., 1978, Black Sea Stratigraphy, in D. A. Ross, and Y. P. Neprochnov, eds., Initial Rep. Deep Sea Drill. Proj., v. 42, part 2: Washington, DC, US Govt. Print. Office, p. 17-26.

Rotaru, A., 2010, Geoenvironmental Issues Concerning the Black Sea Basin: International Journal of Energy and Environment, v. 4, p. 131-138.

Rothwell, R. G., M. S. Reeder, G. Anastasakis, D. A. V. Stow, J. Thomson, and G. Kahler, 2000, Low sea-level stand emplacement of megaturbidites in the western and eastern Mediterranean Sea: Sedimentary Geology, v. 135, p. 75-88.

Ryan, W. B. F., W. C. Pitman, IIIrd, C. O. Major, K. M. Shimkus, V. Moskalenko, G. A. Jones, P. S. Dimitrov, G. Gorür, M. Sakinç, and H. Yüce, 1997, An abrupt drowning of the Black Sea shelf: Marine Geology, v. 138, p. 119-126.

Sorokin, V. M., A. G. Roslyakov, and V. V. Yutsis, 1998, New data on the structure of the upper Danube deep-sea fan: Lithology and Mineral Resources, v. 33, p. 518-524.

Soulet, G., G. Delaygue, C. Vallet-Coulomb, M. E. Böttcher, C. Sonzogni, G. Lericolais, and E. Bard, 2010, Glacial hydrologic conditions in the Black Sea reconstructed using geochemical pore water profiles: Earth and Planetary Science Letters, v. 296, p. 57-66.

Soulet, G., G. Ménot, G. Lericolais, and E. Bard, 2011, A revised calendar age for the last reconnection of the Black Sea to the global ocean: Quaternary Science Reviews, v. 30, p. 1019-1026.

Stanev, E. V., 2005, Understanding Black Sea dynamics; An Overview of Recent Numerical Modeling: Oceanography, v. 18, p. 56-75.

Stanev, E. V., J. A. Simeonov, and E. L. Peneva, 2001, Ventilation of Black Sea pycnocline by the Mediterranean plume: Journal of Marine Systems, v. 31, p. 77-97.

Stanev, E. V., J. Staneva, J. L. Bullister, and J. W. Murray, 2004, Ventilation of the Black Sea pycnocline. Parameterization of convection, numerical simulations and validations against observed chlorofluorocarbon data: Deep Sea Research Part I: Oceanographic Research Papers, v. 51, p. 2137-2169.

Stanley, D. J., 1983, Mud Carrying Turbidity Currents on the Slope Resulting in Unifites on Basin Plains: Journal of the Geological Society, v. 140, p. 978-978.

Talling, P. J., R. B. Wynn, D. G. Masson, M. Frenz, B. T. Cronin, R. Schiebel, A. M. Akhmetzhanov, S. Dallmeier-Tiessen, S. Benetti, P. P. E. Weaver, A. Georgiopoulou, C. Zuhlsdorff, and L. A. Amy, 2007, Onset of submarine debris flow deposition far from original giant landslide: Nature, v. 450, p. 541-544.

Tekiroglu, S. E., V. Ediger, S. Yemenicioglu, S. Kapur, and E. Akca, 2001, The experimental analysis on the Late Quaternary deposits of the Black Sea - (Analyse de sediments holocenes de la Mer Noire). Oceanologica Acta, v. 24, p. 51-67.

Tockner, K., U. Uehlinger, and C. T. Robinson, 2009, Rivers of Europe, Elsevier Ltd., 728 p.

Tripsanas, E. K., W. R. Bryant, and B. A. Phaneuf, 2004, Depositional processes of uniform mud deposits (unifites), Hedberg Basin, northwest Gulf of Mexico: New perspectives: Aapg Bulletin, v. 88, p. 825-840.

Vail, P. R., and R. M. Mitchum, 1977, Seismic Stratigraphy and global changes of sea-level, Part 1 Overview, in C. E. Payton, ed., Seismic Stratigraphy - Applications to Hydrocarbon Exploration: Amer. Assoc. Pet. Geol. Bull., v. Mem. 26: Tulsa, Oklahoma, Payton, C. E., p. 52-53.

Winguth, C., H. K. Wong, N. Panin, C. Dinu, P. Georgescu, and Anonymous, 1998, Pleistocene sea level changes and sedimentation in the northwestern Black Sea.; AGU 1998 fall meeting: Eos, Transactions, American Geophysical Union, v. 79, p. 473.

Winguth, C., H. K. Wong, N. Panin, C. Dinu, P. Georgescu, G. Ungureanu, V. V. Krugliakov, and V. Podshuveit, 2000, Upper Quaternary water level history and sedimentation in the northwestern Black Sea: Marine Geology, v. 167, p. 127-146. 
Wong, H. K., N. Panin, C. Dinu, P. Georgescu, and C. Rahn, 1994, Morphology and post-Chaudian (Late Pleistocene) evolution of the submarine Danube fan complex: Terra Nova, v. 6, p. 502511.

Wong, H. K., C. Winguth, N. Panin, C. Dinu, M. Wollschläger, G. Ungureanu, and V. Podshuveit, 1997, The Danube and Dniepr fans, morphostructure and evolution: GeoEcoMarina, v. 2, p. 77-102.

Wynn, R. B., and D. A. V. Stow, 2002, Classification and characterisation of deep-water sediment waves: Marine Geology, v. 192, p. 7-22.

Zaragosi, S., G. A. Auffret, J.-C. Faugères, T. Garlan, C. Pujol, and E. Cortijo, 2000, Physiography and recent sediment distribution of the Celtic Deep-Sea Fan, Bay of Biscay: Marine Geology, v. 169 , p. 207-237.

Zonenshain, L. P., and X. Pichon, 1986, Deep basins of the Black Sea and Caspian Sea as remnants of Mesozoic back-arc basins: Tectonophysics, v. 123, p. 181-211.

Figures

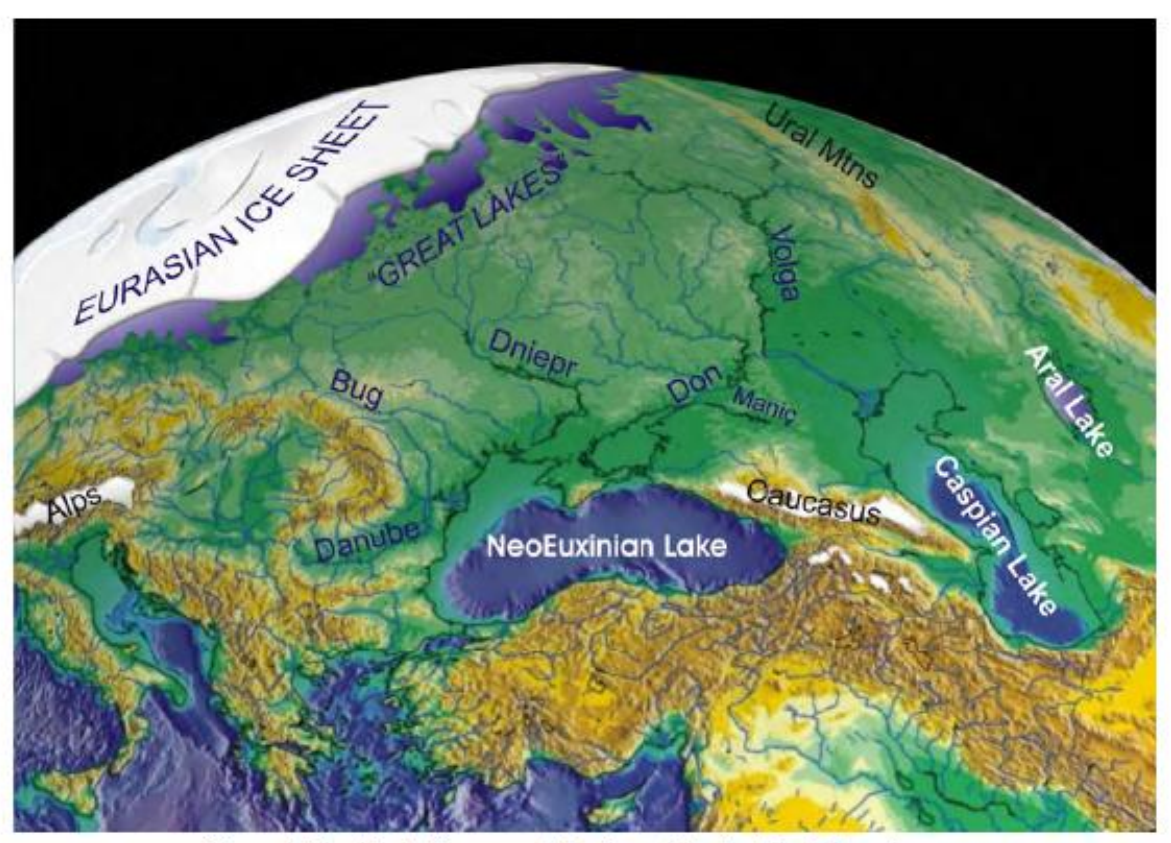

Figure 1. The Black Sea area at the time of the last glacial maximum. 


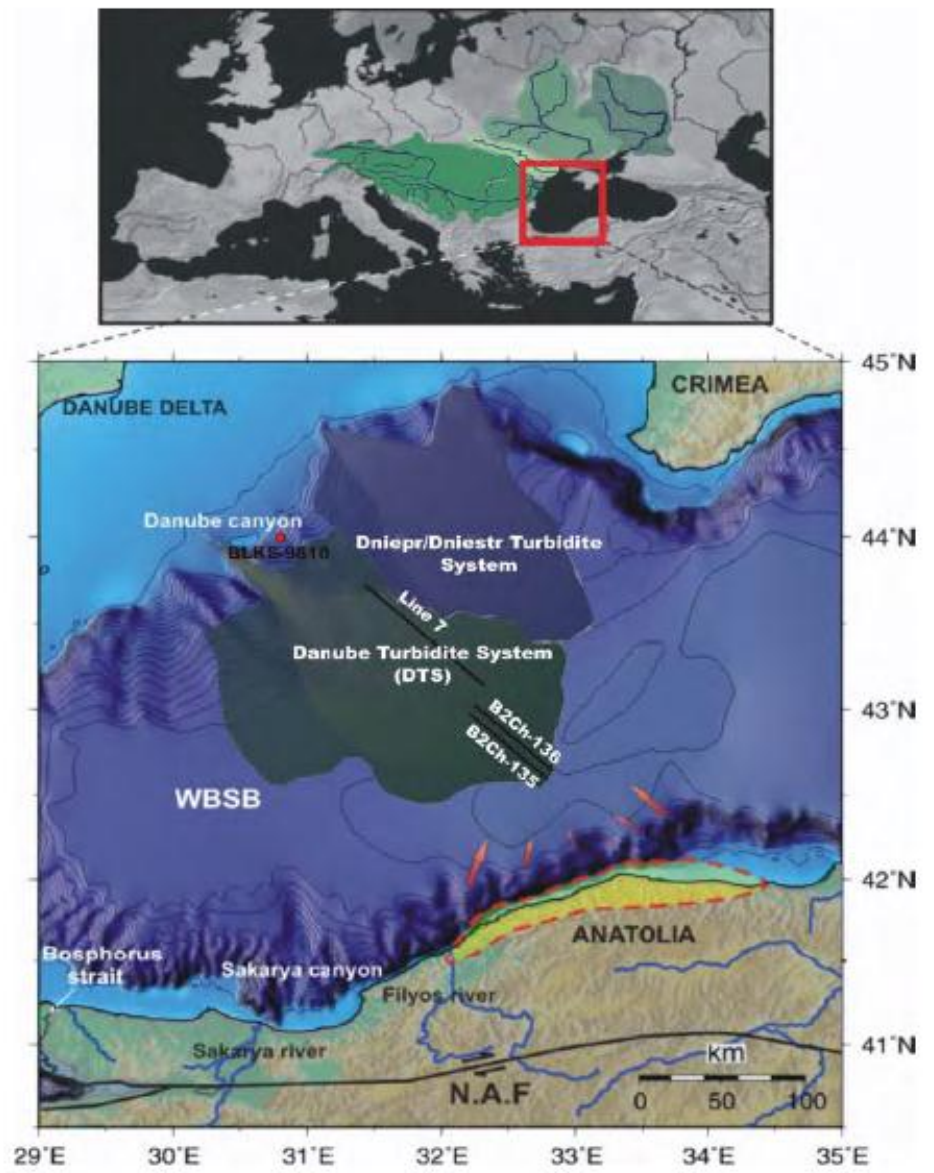

Figure 2. Location map of the study area, showing extension of the two main sedimentary features in the western Black Sea Basin (WBSB): the Danube Turbidite System (DTS) and the Dniepr Turbidite System (after Popescu et al, 2001; after Wong et al., 1997); bathymetry contours are from $50 \mathrm{~m}$ interval (source: ETOPO2); locations of the CHIRP seismic line B2CH-135 and B2CH-136 (black solid line) and of the multichannel seismic line 7; location of the possible sediment source for the portion of the deep basin studied, out of the DTS influence (red dashed line and arrows); location of the North Anatolian Fault (N.A.F). Bathymetric font modified from (Gillet et al., 2007; Lericolais et al., 2012). 


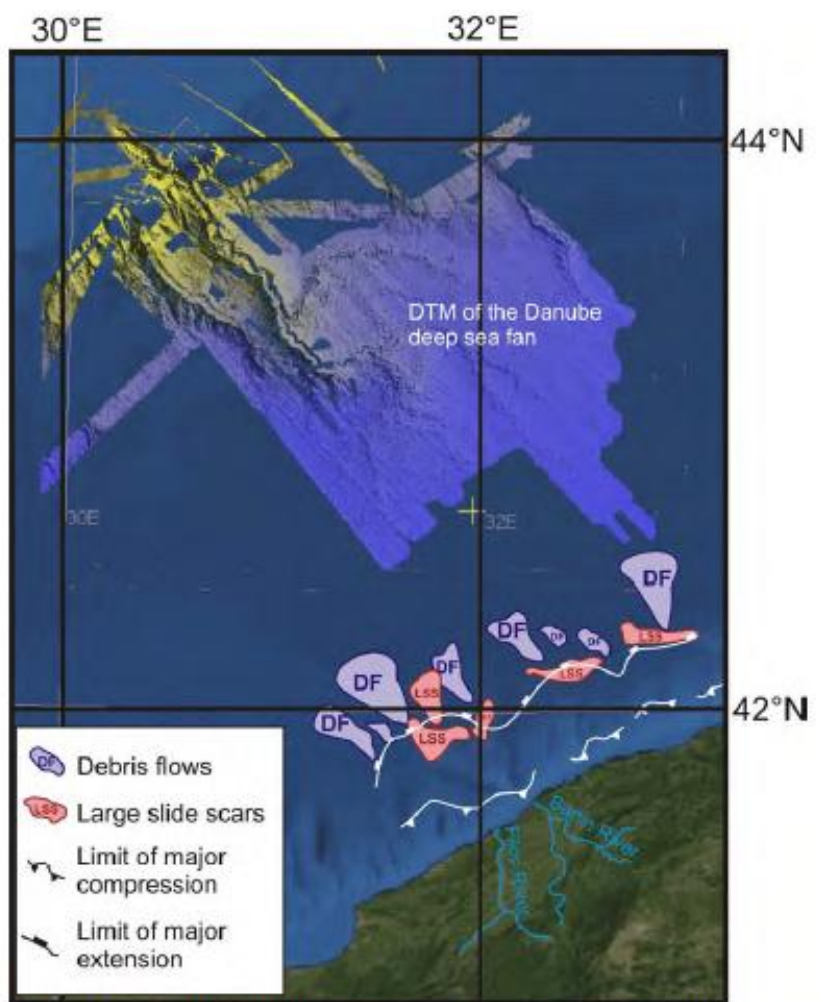

Figure 3. Structural and morphological elements of the southern part of the studied area obtained from acoustic survey carried out by Kücük et al. (2011). This study shows that important debris flows (DF) and large slide scars (LSS) are present on this tectonically active margin and could reach the distal part of the Danube deep sea fan. The DTM of the Danube deep Sea fan has been studied by Lericolais et al. (2012).

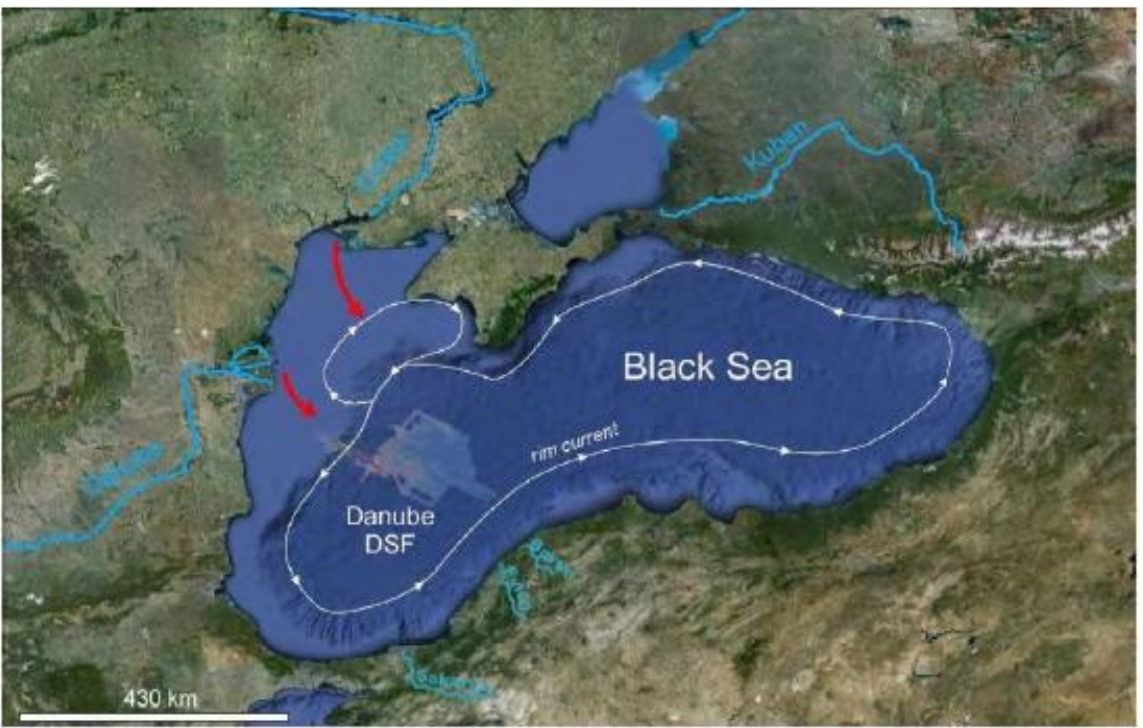

Figure 4. Regional setting of the Black Sea, showing the main drainage systems and offshore rim currents. Red arrows point out major sediment discharges at river mouth. 


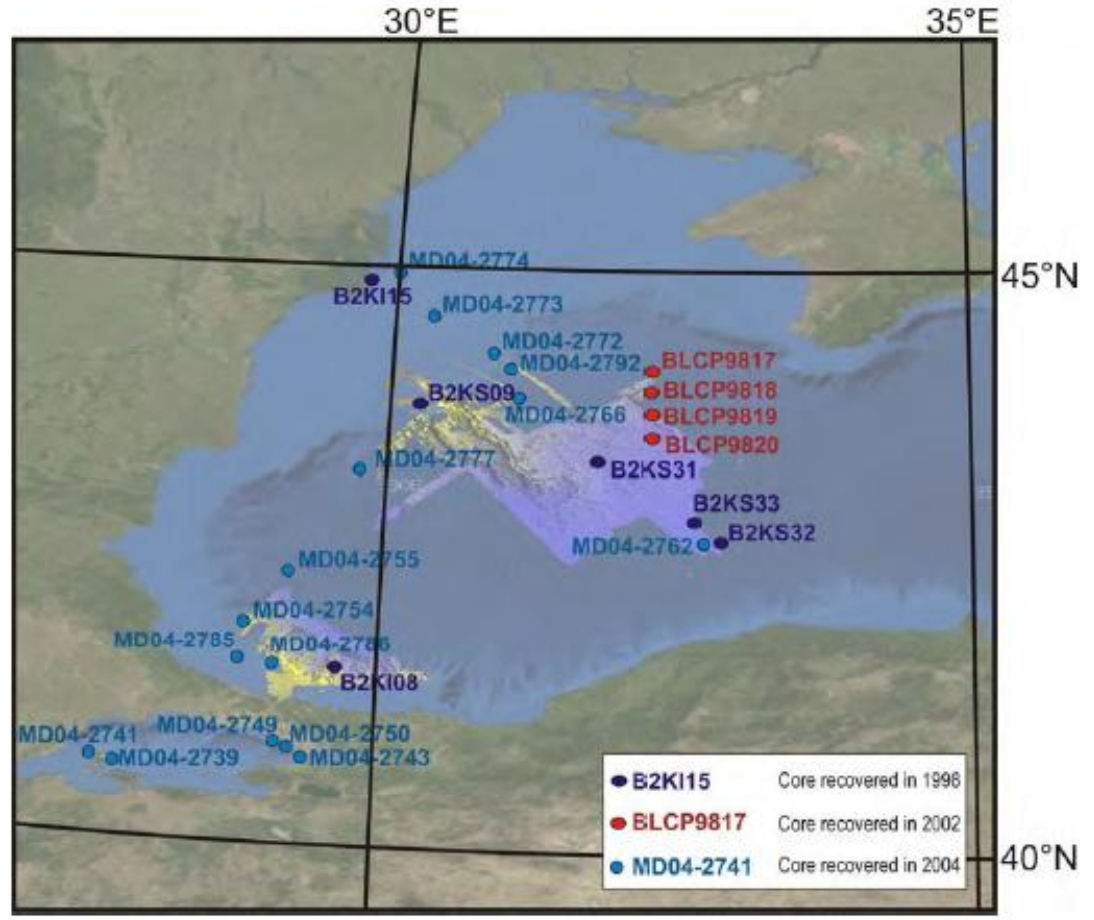

Figure 5. Location map of Black Sea cores used for the rare earth element analyses.

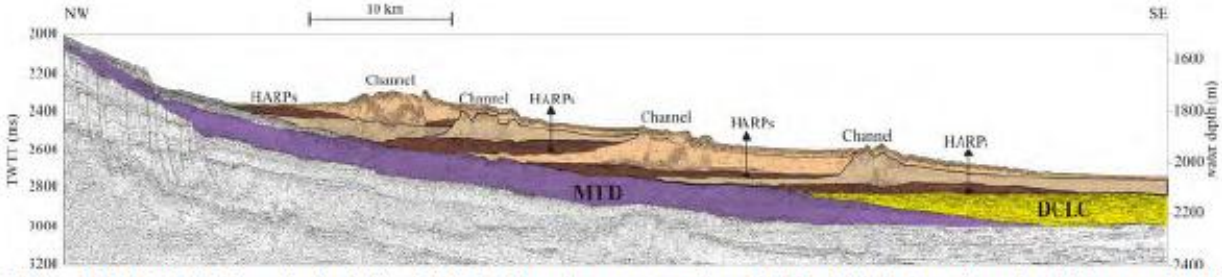

Figure 6. Part of BLASON 24-Channel seismic line 7: MTC = Mass transport complex; DCLC $=$ Distributary channel and lobe complex; HARPs = High amplitude reflection packets. Modified from Popescu et al. (2001) 


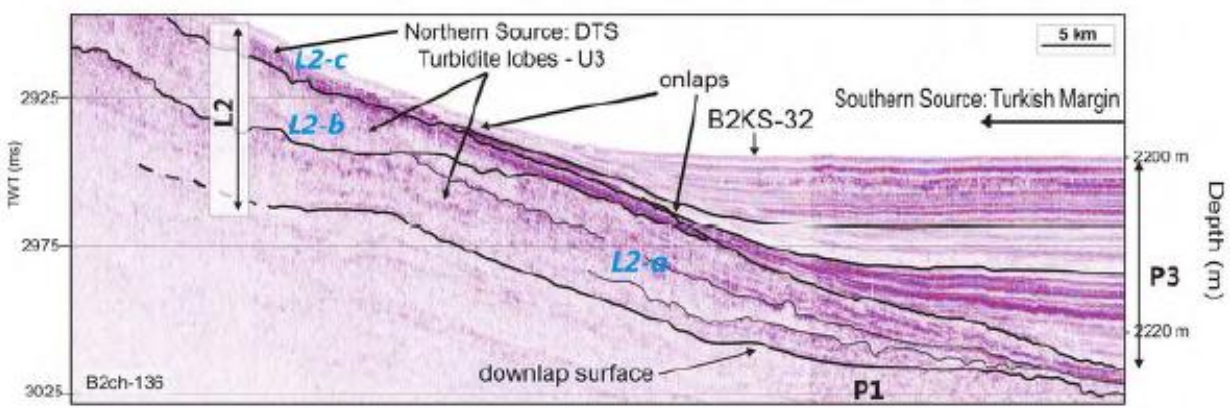

Figure 7. CHIRP seismic profile B2ch-136 showing core location for B2KS-32. Seismic units P1 and P3 are associated with fine-grained distal turbidites. Unit L2 corresponds to a chaotic to bedded continuous reflections package. L2-a, L2-b and L2-c are three sub-units of L2 corresponding to three individual depositional bodies ( $c f$. Lericolais et al., 2012).

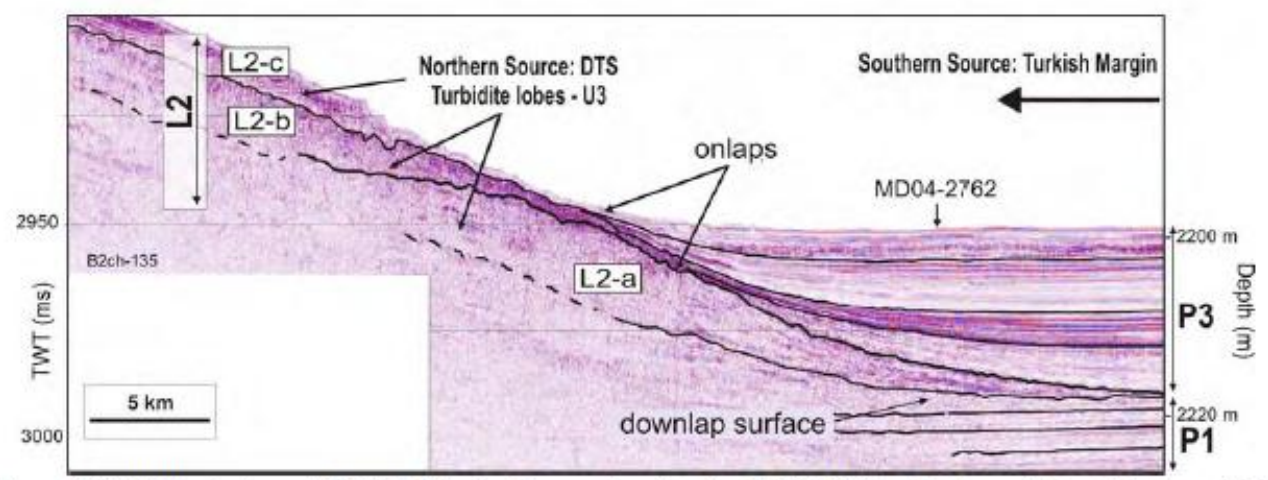

Figure 8. CHIRP seismic profile B2ch-135 showing core location for MD04-2762 and interpretation. Seismic units P1 and $\mathrm{P} 3$ are associated with fine-grained distal turbidites. Unit $\mathrm{L} 2$ corresponds to a chaotic to bedded continuous reflections package. L2-a, L2-b, and L2-c are three sub-units of L2 corresponding to three individual depositional bodies (cf., Lericolais et al., (2012). 


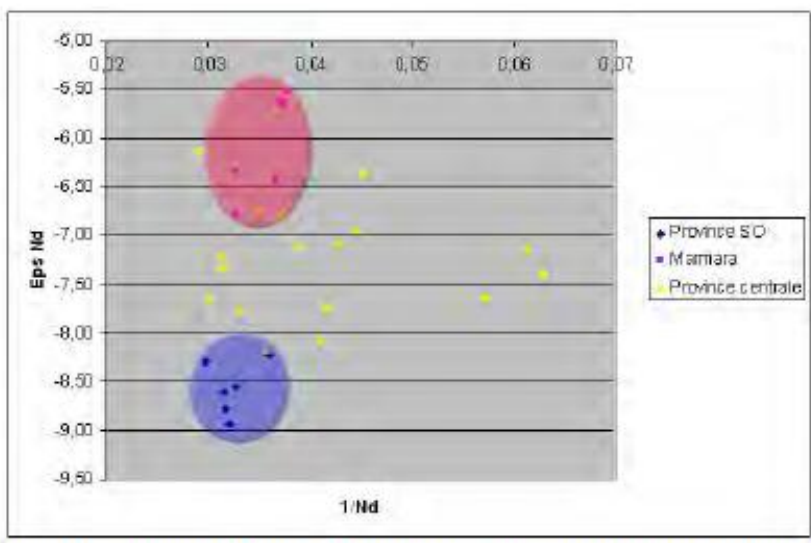

Figure 9. Neodymium isotope composition (eNd) against Nd concentration (shown as $1 / \mathrm{Nd}$ pmoll). Two poles are well identified: (1) Pink pole corresponds to the Marmara pole characterized by low eNd and a low $1 / \mathrm{Nd}$ value as well; and (2) Blue pole corresponds to the southwestern Black Sea province (Province SO) having the same value as the core sediment recovered in front of the Danube delta. Yellow dots are values between the two poles. Three values are characterized by high values of $1 / \mathrm{Nd}$ but are considered as not representative, probably consequence of presence of residual carbonates not washed over by the acetic acid. 